\title{
Reference Service: The New Dimension In Librarianship
}

By SAMUEL ROTHSTEIN

I COULD BEGIN where almost everyone else begins and define reference work, but I won't. Instead, I prefer to begin with the more logical beginning-the absence of reference service.

Reference service is so much a commonplace of present-day American library practice that many of us have tended to regard it as an inherent element of librarianship, something that was always done, something whose place in the library order of things is more or less settled. Yet a consideration of foreign library practices would show that reference work is still by no means universally regarded as a fundamental part of library service. I can recall, for instance, that right here in Canada, where I assure you we consider ourselves reasonably advanced in our methods, as recently as ten years ago only one Canadian university library had a reference department formally labeled as such. I have no personal experience of libraries on other continents, but from my reading I would consider it a fair assumption that the term and the service would both still be something of a novelty outside the United Kingdom.

Even in the United States the reference librarian is relatively a Johnny-comelately on the library scene. May I remind you that in the United States of less than a century ago the library still took no responsibility whatsoever for the provision of personal assistance to its users. Of course, there were instances aplenty of personal helpfulness by librarians, but these were made as a matter of simple courtesy rather than of responsibility.

Consider, if you will, how diffidently
A talk given by Dr. Rothstein, Associate University Librarian, University of British Columbia Library, at a meeting of the Reference Services Division of ALA in Montreal on June 22, 1960.

the case for such service was first put. When a pioneer of American reference work such as Samuel Swett Green of the Worcester Public Library first began to realize that the traditional policy of laissez faire was inadequate to meet the needs of readers, he ventured no more than to champion what he called-and it is still my favorite title for a library paper-“the desireableness of . . . personal intercourse between librarians and readers." 1

That was in 1876, and Green had good reason to be modest in his claims; he was backing a pretty dark horse in the endless race for funds and attention. For a generation thereafter American librarians debated the value of the new service. While there were supporters enough for what they termed "access to librarians," many libraries were still inclined to doubt the practicability and value of personal assistance. For example, when the Examining Committee of the Boston Public Library suggested in 1887 that there should be in Bates Hall a "person whose sole duty it would be to answer questions of all sorts, and to direct inquirers in their search for information," the recommendation received the stiff reply from the Trustees that it was hardly

1 Samuel Swett Green, "Personal Relations Between Librarians and Readers," Library Journal, I (1876), 74-81. The longer title was used for the original reading of the paper at tne 1876 conference. 
practicable in that it would require the transfer of personnel from other work! ${ }^{2}$

Well, I can't make a good suspense story out of this conflict, because you already know who won; the name of your division and your numbers here today are the best evidence of the magnitude of that victory. The point of this story is that reference service has not been and is not now an inevitable part of the library order. If libraries simply were limited to "doing what comes naturally," they would acquire, preserve and organize materials, and perhaps make them available. Traditionally, and by the nature of the beast, the librarian's role has everywhere been that of custodian, collector, and cataloger. If in the United States and a few other parts of the world he has also undertaken to furnish personal assistance on an organized basis, it didn't just happen. We have reference service because it was once a "cause"a cause to be propagandized for, an idea to be formulated, developed and brought to fruition!

I say then that both the historical development of reference work in American libraries and its comparative absence in present-day libraries elsewhere strongly suggest that reference service represents a new dimension in librarianship and that its establishment is the product of a more or less deliberate decision. I submit further that the future development of our reference services calls for an equally deliberate decision, and that our chief problem now is to decide on the proper dimensions of that service.

At this point in my argument it seems desirable to make sure that we are all on the same ground by agreeing on a definition of reference service-that is to say, I want you to accept mine. I represent reference work to be the personal assistance given by the librarian to individual readers in pursuit of information; reference service I hold to imply further the

2 Boston Public Library, Thirty-fifth [Annual] Report ... 1887, p. 18 definite recognition on the part of the library of its responsibility for such work and a specific organization for that purpose. In short, we are willing to give help, and what is more, consider such help an important enough part of our obligations to justify training and assigning staff especially for this work.

Now, "help" is a great big tent of a word that embraces an enormous range and variety of activities, and the only way to distinguish the main features of these activities is to categorize or classify them. Putting out of consideration the many behind-the-scenes tasks in a reference department and concentrating only on the actual work with readers, we may first distinguish the groups of assignments that finds us, say, clearing up the mysteries of the filing system in the public catalog; making sure that the reader knows about using the index in the $E n$ cyclopaedia Britannica; directing him to the appropriate division of the library for a given inquiry; in some cases lecturing to a class on the bibliography of a field. In sum, instruction in the use of books and libraries.

We must reserve a second and separate pigeon-hole for the work that we do in response to requests such as; "What are some interesting books on dogs for children?"; "I want to do some systematic reading on psychology, where do I begin?"; "I've finished all the Zane Grey novels; what do I do now?" We used to call this sort of consultation "readers' advisory work", and at one time it bade fair to set up shop on its own, right outside the reference department. I think that it is now back in the fold more often than not, and I shall include it in our roster under the heading guidance in the choice of books.

The last and by far the biggest pigeonhole I allocate for information service. The distinction here is that the librarian supplies the information itself and not just the books where it may be found. We may call this most variegated and

COLLEGE AND RESEARCH LIBRARIES 
most debatable aspect of reference service: getting information out of books.

Instruction in the use of books, guidance in the choice of books, supplying information out of books-these then are the three primary colors in the reference work picture. Almost every respectable library in the United States and Canada does some of each; almost no two libraries mix the colors in quite the same way.

Let us extend this color analogy somewhat further and trace the reference spectrum. At one end we may have $\mathrm{Li}$ brary A, say, a smallish public library. It has two public service librarians (they don't call themselves reference librarians) who are kept pretty busy by an eager clientele of high schoolers and housewives. They do their best to help the students with their assignments, but are very careful to avoid what they call "spoonfeeding" them. They will show them where to look for an answer but would no more hand them a fact than they would the key to the vault. With the adults they are more likely to "dig up the answer", but only if it is narrowly factual enough for them to be able to find it in a reference book. Anyway, few people really think of referring to this library for specific information. They get that by asking each other, or writing away for it, or most likely just do without it. The men in the community regard this library as a kind of cultural monument which fulfills its function by just existing. Their wives know that the library offers a good deal of light reading too, and the librarians exert devious but determined efforts to inculcate in them a taste for better books. Sometimes they are successful; mostly they are not and are regarded simply as the "library ladies" who look after the collection.

Our next spectroscopic reading shows us Library B, a university library of some size and consequence. The reference librarians here are very self-consciously such, and they take deserved pride in their professional skill. They dextrously and sympathetically steer the bewildered newcomer into the easy familiarity with indexes, subject-headings, and bibliographies that constitutes "library knowhow." Occasionally, mind you, they find it easier to supply the date or the population figure outright than to show the inquirer how to get it, but they keep a wary eye out for the cunning student whose pretended ignorance would lure them into doing his assignment for him.

For graduate students and faculty the reference librarians are willing to do much more: verify a footnote, trace a quotation, identify an obscure name, sometimes even compile a bibliography. They rather enjoy a "difficult question," and delight in the challenge it offers to their ingenuity and knowledge. They shy away, however, from summarizing data or interpreting it; they take no responsibility for the validity of the information they furnish.

The last spectrograph depicts a special library in action. Mr. X, is in charge of the library that serves the research staff of a chemical firm. He calls himself a special librarian or an "information officer" or perhaps even a documentalist. He doesn't worry a bit about doing anyone else's work for him; in fact, he believes that that is what he is there for. He compiles bibliographies, does literature searches, submits reports on the "state of the art." He tries to anticipate questions by distributing abstracts of articles pertinent to the current research projects. At times he may prepare translations or even take a hand in editing material for publication. In short, he holds himself almost completely responsible for the "literature side" of his firm's research, and thereby frees his patron's time for concentration on the "laboratory side" of their projects.

You all recognize these libraries, but you may never have stopped to realize that each bases its service on a different 
theory of reference work, or to examine the reasoning these rest upon. James Ingersoll Wyer identified these theories as "conservative," "moderate" and "liberal,"3 but I prefer the more mnemonic and alliterative sequence of "minimum," "middling" and maximum."

The minimum theory bases its case on education and fear. The library admittedly has an obligation to assist the inexperienced reader, but it serves him, best, so this argument goes, when it limits its help to showing him how. To which the minimal theory would add by way of corollary the supposition that the experienced reader or scholar does not want or requires more than occasional personal assistance. Ainsworth Rand Spofford wrapped all this up neatly in his dictum of sixty years ago: "It is enough for the librarian to act as an intelligent guide-post, to point the way; to travel the road is the business of the reader himself."4

Of course even the minimum reference department does offer something of an information service, but diffidently. And here is where the fear comes in. Fear, first of all, that the library can never hope to have the manpower to render more than severely limited assistance. Fear, again, that the patrons will take undue advantage and make exorbitant demands. And finally, errorophobia, my new word for that old malady: the librarian's fear of making a mistake. You know the feeling-the world of knowledge is so large and much of it so hopelessly specialized; let's play safe by sticking to our friendly reference books and ready reference questions. No mistakes, no worries-also not much service.

In sharp contrast, the maximum theory of reference work takes its stand on the twin tenets of faith and efficiency. Information, it contends, is of crucial con-

3 James Ingersoll Wyer, Reference Work: a Textbook for Students of Library Work and Librarians. (Chicago: American Library Association, 1930), pp. 6-7.

4 Ainsworth Rand Spofford. A Book for All Readers (New York: G. P. Putnam's Sons, 1900), pp. 204, 213. cern to many people. For businessmen, legislators, researchers and scholars, it is more important that they have it than that they learn how to acquire it, and extensive library assistance is therefore economical and worthwhile in any case where the time saved by the client is more valuable than the time spent by the librarian. The chemist no longer blows his own glassware and the doctor no longer takes temperatures; why should they not have the librarian conduct literature searches for them? And where efficiency suggests the librarians should, faith says the librarian can do these things, and perhaps even better than the client himself. Given the requisite subject knowledge and sound bibliographical training, the librarian can, in this view, become the specialist in "finding out," even to the point of validating the data he secures.

Between the "conservatives" and the "liberals" stand the "moderates" ... in the middle and, I fear, in a muddle. They affirm the pedagogical superiority of instruction over direct provision of information, but wonder whether this is an appropriate reason to limit assistance to their non-student clientele. They want to promote demand for the library's service, but are unwilling to extend the scope of the service most in demand. They range wide but seldom deep. Expediency vies with principle.

The result is a pattern of wonderful inconsistency. I have the impression that the patron who comes to a public library looking for, say, Babe Ruth's home run record, is likely to be directed to Menke's Encyclopedia of Sports; if he were lazy enough to telephone instead, he would find that the same reference department ran a very efficient information service. I know from personal experience that an ingenious student can, by writing a plausible letter to a neighboring university, have compiled for him the bibliography that his own library would never produce. A request from the City $\mathrm{Hall}$ or the 
President's Office produces wonders of reference work.

Do I seem to you to have presented an inaccurate picture of the three theories? I have no doubt that my slips and prejudices have been showing, and I now abandon the attempt at impartiality and give you my own opinions.

I say first of all that we should give up our reservations about the direct provision of information and recognize information service as a principal and worthy obligation of the library, something we should try to push forward as far as we can. Let us admit frankly that our instructional efforts are logically applicable only to students, and that our other customers have no more reason to be guided in the techniques of finding out than they have in being shown how to fix a defective carburetor. Again to quote Wyer: "It is service, not suggestion, that is at a premium."5

Wyer made his statement three decades ago, and I believe that the value and need of such service have mounted with the years. For the general public there is now greater need than ever for the public library to serve, in W. S. Learned's famous phrase, as "the community intelligence service." media of mass communication assault us every day with a barrage of distortions and half-truths, the public library can make an almost unique contribution by serving the community's center for reliable, detailed information. The public library may sometimes find it hard to compete with television, picture magazines and the like when it comes to furnishing entertainment and escape. But why compete? I hold with Dr. Robert Leigh and the Public Library Inquiry that the natural and appropriate role of the public library in our time is to emphasize and develop the kinds and quali-

5 Wyer, op. cit., p. 9.

Williams S. Learned. The American Public Library and the Diffusion of Knowledge (New York: Harcourt, Brace, 1924), p. 14. ties of service that the mass media are not equipped to give. ${ }^{7}$

In the libraries that serve scholars and research scientists, the case for an amplified reference service is even stronger. In the first place, it may be conceded that the social importance of their work warrants these people special consideration. More important is the fact that research workers stand in growing need of a fullscale reference service. A recent textbook on the theory and practice of industrial research puts it this way: "It is inefficient to expect a research worker to obtain all this information on his own. In any case, it is barely possible for him today to keep up with current information in his own particular specialty, much less maintain his contracts with other fields. The library ... staff ... in any efficient research group must maintain or have access to all the sources of information which would be of utility to a worker in a given project. For best results, they should be able to prepare bibliographies and abstracts of pertinent material rapidly and to furnish specific literature which the researchers feel would be of additional interest." 8

This statement brings out the chief reason for the increasing dependence of research workers upon librarians. I refer, of course, to the astounding proliferation of scientific literature since the Second World War. All of us have seen the fearsome statistics that prove this point, and it is now quite evident that the volume of pertinent literature in any single field, except possibly in the most narrow specializations, has outstripped the capacity of the individual research man to cope with it unaided.

The scientist's bibliographical difficulties are compounded by a number of other factors: the acknowledged deficiencies of the abstracting and indexing

\footnotetext{
7 Robert Leigh, The Public Library in the United States (New York: Columbia University Press, 1950), p. 46.

${ }^{8}$ David Bendel Hertz, The Theory and Practice of Industrial Research (New York: McGraw-Hill Book Company, 1950), p. 303.
} 
journals in covering the literature; the present-day tendency to publish results in the relatively inaccessible "technical reports" rather than in the standard journals; the fact that scientific research has increasingly emphasized the interdisciplinary approach and hence has forced the researcher to gain cognizance of work done outside the realm of his own bibliographic competence. Without going into details on these much-discussed matters, I think I am quite safe in concluding that the task of tracing and using scientific literature has become considerably more difficult in the last decade. The effect, it seems to me, is to justify a place for an intermediary between the research man and his literature, and to suggest that the location of information almost necessarily becomes a specialized function devolving upon specially assigned personnel.

You will have already noticed that, in the foregoing analysis, I have leaned rather heavily on the reference librarian's potential contribution to scientific research. It is certainly true that the subdivision of labor implied in this relationship is more readily applicable to the physical sciences and technology than it is to research in the humanities and social sciences. It is, I concede, equally true, that by far the greater number of people actually functioning in this capacity of "research librarian" (or call him what you will) work in libraries attached to industrial research laboratories or in scientific institutes.

Yet I refuse to admit that the reasoning that makes an amplified reference service feasible and desirable for scientific research does not extend to other fields of investigation. The humanities and social sciences suffer from a like proliferation of publication. Team research and interdisciplinary research are certainly no novelties here, either. And most convincing of all is the fact that a research service, catering especially to the humanities and social sciences, has actually worked very well in such institutions as municipal and legislative reference libraries, special libraries, and, not infrequently, in university libraries. May I recall to you the "research librarianships" established with Carnegie Corporation funds a generation ago? At Cornell and Pennsylvania, these "research librarians" engaged in such projects as: a report on methods used in handling strikes in Australia; biographical sketches of sixty-four early British writers on economics; a study of King Charles I's theory of government as indicated in his speeches. ${ }^{9}$

And this was the confidential judgment rendered on this service by one of the most eminent humanists at the University of Pennsylvania: "It was of the utmost value. I have never habituated myself to obtaining help in such research as I have done, and it was a surprise and satisfaction to find the immense advantage of such trained and intelligent help ... I have not the least doubt of the value of such assistance. I was not so sure of it at first. The only difficulty, it seems to me, is on our part, that is, to formulate our problems in such a way as to make his contifbution to their solution available."10

This is glowing testimony, and I wish the situation were quite as this famous scholar pictured it. I wish indeed that the "only difficulty" about an amplified reference service were on the part of the recipients. You and I know that "it just ain't so." We know that the Carnegie Corporation's scheme of "research librarianships" never spread beyond the two universities of the original demonstration. We remember that the Detroit Public Library's plan for an Industrial Research Service died aborning.

It is all too easy to see the large practical difficulties that attend any grand-scale information service: the need for highly-

\footnotetext{
- Cf. Samuel Rothstein, The Development of Reference Services . . (ACRL Monographs, Number 14. Chicago: Association of College and Reference Libraries, 1955.), p. 94.

10 Quoted in Rothstein, op. cit., p. 95.
} 
trained staff that can combine high bibliographical skill with special subject knowledge; the problem of discriminating between the trivial and the important request; above all, the problem of numbers. I recall being told some years ago on a visit to the New York Public Library that, in the Information Division there, each reference librarian was expected to deal with fifty to sixty inquiries an hour! I could only shake my head.

I do not have ready-made, overall answers to these genuine problems, and indeed it would be presumptuous of me to present such solutions, for these can only be worked out in the individual library, with due regard for the circumstances attending each situation. Every case is special. I do suggest the following possibilities as food for thought:

1. Library budgets $c a n$ be increasedperhaps several times over-without putting the slightest strain on the economy of either the United States or Canada. As a British librarian recently stated, when the cost of a single missile may exceed the combined expenditure on the country's libraries, it is absurd to speak of library costs. The scale of our present services would have seemed utopian a generation ago; why should we see the future as static?

2. The reference services-and especially the information service-can get a large share of the existing library budget. I have no wish to start one more civil war in the ALA, but it may well be that we spend too much money on our technical processes and not enough on our public services. (By the way, I happen to be in charge of technical processes at my library).

3. There seems to be sound reason for hope that advances in library technology can produce savings which could be applied to the expansion of information services. Much of our cataloging, circulation, and acquisitions work can be mechanized, and for that matter, we are promised machines for "information re- trieval" too. In any case the point is the same; the library is freed to concentrate on the really intellectual tasks in librarianship, and prominent among them the information service.

4. A foundation-and of course the Council on Library Resources springs promptly to mind-might be persuaded to sponsor adequate demonstrations of amplified reference service, say adding a dozen subject specialists to each of a number of public and university libraries. In the special library setting the workability and value of such service is already an established fact; what we need to work out now is just how the goal can be realized in the far more complicated context of the general library. The Carnegie Corporation "research librarianships" constituted a test of sorts, but were hardly conclusive. A full-scale experiment is now in order.

And now may I permit myself a few last words of summary and peroration. Historically and indeed in most of their present-day functions librarians have been technicians, handmaidens of both sexes, who work with books rather than in them. When reference service and particularly an information service became established as a regular part of American library practice, it really constituted a new dimension in librarianship; we began to deal in knowledge and not just volumes.

It was a radical idea, a big idea, but sometimes I fear that we have been guilty of considering it too big for us. Though the concept and techniques of an information service began in the general library, we general librarians have been diffident about exploiting it. Other people have done so, and very effectively; now they threaten to establish themselves as a wholly separate profession. History gainsays them, but our claims must rest on more than history. Both the needs of our clients and our own selfinterest say that we should look for ways to work at greater range and depth, to do 
always more not less. If first-class reference service is valuable enough for the businessman to buy, then it is also important enough for the community and the university to support.

This is a large objective, and to reach it we must somehow surmount great practical difficulties. But I would remind you that practical solutions are always a secondary matter; what comes first is conviction. If we can achieve a clearcut decision on direction and policy, if we can settle on ends, I have no doubt that we can find some of the means.

\section{Problems of College And University Libraries}

The Council for Financial Aid to Education has published Wake Up and Read, a Few Facts About College and University Libraries as one of its series of leaflets on the nature and needs of higher education in the United States. The leaflet emphasizes the importance of libraries in higher education and summarizes their need for increased financial support.

The pamphlet cites the fact that financing library series is a major problem to colleges and universities. "More than one president," it declares, "has said that this problem is second in urgency only to that of raising faculty salaries."

It points out that the percentage of increase in expenditures has not kept abreast the increases in total institutional expenditures in a representative sampling of libraries. It notes that the medium beginning salary for professional librarians had, by $1958-59$, risen only to $\$ 4,500$ while the U. S. Department of Labor estimated in 1960 that starting salaries for college graduates with bachelor's degrees only would average $\$ 5,400$.

"Viewed in the large," summarizes the Council's leaflet, "the expansion of services, the improvement of building plans, the raising of personnel standards for staff, and the building of collections are not examples merely of library progress, but part of the total program of improvement in higher education in the United States. That is why everybody-university administrators, teachers, parents, legislators, and the general citizen-has a stake in the future of the college and university library."

A copy of the pamphlet has been sent with the compliments of ACRL to the libraries of each institution listed in the U.S. Office of Education's directory of colleges and universities. Additional single copies may be secured from the ACRL office or from the Council at fifteen cents each. Orders for twenty or more copies can be filled by the Council at a 40 per cent discount on the single-copy price. The address of the Council for Financial Aid to Education, Inc., is 6 East 45 th Street, New York 17, N. Y. 